\title{
cDNA Cloning, Prokaryotic Expression of Two Splicing Products of mLRG, a Mouse Gene of Lipopolysaccharide Response
}

\author{
Zhongming Dai ${ }^{12^{*}}$, Zanguo $\mathrm{Nie}^{2 *}$, Liang $\mathrm{He}^{3}$, Lina Guan4 ${ }^{4}$ Yunsheng Yang1 \\ ${ }^{1}$ Department of Digestive Disease, Chinese PLA General Hospital, Beijing, China \\ ${ }^{2}$ Department of Digestive Disease, Urumuqi Military General Hospital, Urumuqi, China \\ ${ }^{3}$ Department of General Surgery, Urumuqi Military General Hospital, Urumuqi, China \\ ${ }^{4}$ Department of Stomatology, Urumuqi Military General Hospital, Urumuqi, China \\ Email:64849787@qq.com
}

Received 3 November 2015; accepted 27 November 2015; published 30 November 2015

Copyright (C) 2015 by authors and Scientific Research Publishing Inc.

This work is licensed under the Creative Commons Attribution International License (CC BY). http://creativecommons.org/licenses/by/4.0/

(c) (i) 0 pen Access

\section{Abstract}

Aim: To clone two splicing products of the mouse mLRG-cDNA and to express mLRG protein. Methods: The sequence obtained was compared human Irg to mouse genome with a comparative BLAST genome search and found completely identical. We spliced some fragments to a whole mouse $\mathrm{Irg}$-cDNA sequence and designed a pair of primers at completely homologous fragments in 5'-UTR and 3'-UTR, we amplified mouse Irg-cDNA by RT-PCR. Then the sequence encoding the mLRG protein was amplified by RT-PCR from the total RNA of NIH3T3 cell stimulated by lps (lipopolysaccharide), and we got two splicing products of mLRG (mLRGW, mLRGS) and two sequences encoding protein were cloned into the prokaryotic expression vector pTAT so as to construct the recombinant expression vector pTAT-MLRGW and pTAT-MLRGS. The proteins were expressed in $E$. coli BL21 (DE3). Results: We got a cDNA fragment with the length of $1905 \mathrm{bp}$. Its location is at chromosome X qF4 site and we amplified two encoding regions covered $1554 \mathrm{bp}$ and $1404 \mathrm{bp}$ respectively ( $\mathrm{mlrg} W \mathrm{~m} / \mathrm{rg} S$ ). His-TAT-mLRGW and His-TAT-mLRGS fusion protein were expressed successfully. $m \operatorname{lrg} W$ is consist of 10 exons and 9 introns; $m I r g S$ is consist of 11 exons and 10 introns. Conclusion: Cloning of two splicing products of mouse novel gene MLRG and prokaryotic protein expressions are of help in the further study of this gene.

\section{Keywords}

mLRG, Lipopolysaccharide Response Gene, cDNA Cloning, Prokaryotic Protein Expression

\footnotetext{
${ }^{*}$ Co-first authors.
} 


\section{Introduction}

To date, primary protein lipopolysaccharide responses investigated are lipopolysaccharide (LPS) binding protein (LBP), soluble CD14 and Toll-like receptor 4 (TLR4). The mechanism of these proteins regulate is perplexing.

The binding of LPS to CD14 initiates a wide variety of biological reactions mainly occurring in monocytic cell lineages [1]. Since CD14 is not a trans-membrane protein, it couples with the trans-membrane protein, Toll-like receptor 4 (TLR4) and initiates intracellular signaling cascades [2] [3]. Soluble CD14 (sCD14) complexed with LPS also activates endothelial cells via TLR4 to induce microcirculatory disturbances [4]-[8]. The important roles of CD14 as the LPS recognition molecule in vivo have also been explored using CD14 transgenic and knockout mice [9]-[11].

LPS binding protein (LBP) and CD14 play key roles in promoting innate immunity to Gram-negative bacteria by transferring LPS to the signaling receptor complex, MD-2/Toll-like receptor 4 (TLR4). The dual stimulatory and inhibitory mechanisms of sCD14 and LBP may benefit the infected host by promoting inflammation in local sites, where it is needed, while at the same time preventing potentially detrimental systemic responses to LPS [12]. However, the mechanism of LPS-stimulated tissues damage remains obscure.

A number of studies have investigated the impact of LPS and other bacterial products on apoptosis of white blood cells. In vitro, LPS has been shown to promote apoptosis in macrophages [13]-[15] but to inhibit apoptosis of neutrophils [16] [17]. In vivo LPS has a pro-apoptotic effect on lymphocytes in Peyer's patches and thymocytes, whereas it has anti-apoptotic effects in peritoneal neutrophils [18]-[20]. Mani Alikhani, Zoubin Alikhani et al. demonstrated that lipopolysaccharides indirectly stimulate apoptosis and global induction of apoptotic genes in fibroblasts through experiment, but number of gene participate in this procedure is more than forty [21]. So we need to search for upstream gene from cells LPS-stimulated to elucidate the mechanism of LPS damage.

Human lipopolysaccharide response gene (hlrg) was cloned from LPS-stimulated human dental pulp cell by the method of Improved PCR-based subtractive hybridization strategy [22] by Ph.D Chai YB of our teams in 1999 (Accession No. AF143740) [23]. We found a more complete novel human lrg cDNA in GenBank database BLAST search (Accession No. AK002071). It may be relative of endotoxin response. Mouse lipopolysaccharide response gene $(\mathrm{lrg})$ is not reported. We compared human lipopolysaccharide response gene (lrg) for mouse ESTs in GenBank database BLAST search [24] and spliced good homology segments to a predicted mouse lipopolysaccharide response gene ( $\mathrm{lrg}$ ) sequence [25]. We designed a set of primers at completely homologous fragments in 5'-UTR and 3'-UTR, and amplified two mouse $\mathrm{rg}$-cDNA sequences by RT-PCR. We got mouse lipopolysaccharide response whole gene (mLRGW) and mouse lipopolysaccharide response splice gene (mLRGS) prokaryotic protein expressed production. Cloning of two splicing products of mouse novel gene mouse lipopolysaccharide response gene (mLRG) and prokaryotic protein expressions are of help in the further study of this gene.

\section{Methods and Materials}

\subsection{Prediction of Mouse lrg}

Comparing human lipopolysaccharide response gene $(\operatorname{lrg})$ to mouse genome with a comparative BLAST genome search and searching completely identical. Splicing some fragments to a whole mouse $\operatorname{lrg}$-cDNA sequence and designing a set of primers at completely homologous fragments in 5'-UTR and 3'-UTR (P1: GCTGCCGTCACCTCATGG, P2: TTCACATCAAGGAACCATCG).

\subsection{Isolation of RNA}

NIH3T3 cells were plated on 150-mm glass culture dishes at a density of $\sim 7 \times 10^{6}$ cells/plate. Cells were treated with (final concentration $100 \mu \mathrm{g} / \mathrm{ml}$ ) lps stimulation for approximately $24 \mathrm{~h}$ prior to cell lysis. Cell extracts were prepared at $4^{\circ} \mathrm{C}$; the cells were washed twice with phosphate-buffered saline and lysed in Trizol reagent (purchased from Invitrogen company). Total cellular RNAs were extracted from cells according to the manufacturer' instructions.

\subsection{Synthesis of cDNA Library and Amply Mouse Irg}

The extracted RNA (500 ng) was reverse transcribed into cDNA first-strand using 200 U of Moloney Murine 
Leukemia Virus Reverse transcriptase (Promega, madison, USA) and 1 mg of oligo (dT) 15 primer (Promega) in a final volume of $25 \mu \mathrm{l}$ of enzyme buffer (Promega) for $60 \mathrm{~min}$ at $42^{\circ} \mathrm{C}$. This cDNA first-strand was taken as template for RT-PCR. PCR was performed with $2 \mu \mathrm{L}$ of cDNA first-strand and 0.01 pmol of each primer (P1, $\mathrm{P} 2$ ), in a $50 \mu \mathrm{L}$ reaction volume containing $100 \mathrm{nmol} \mathrm{MgCl}_{2}, 10 \mathrm{nmol} \mathrm{dNTPs}, 2.5 \mathrm{U}$ of Taq DNA polymerase (Promega), and $5 \mu \mathrm{L} 10 \times$ Taq DNA polymerase buffer. The reaction mixture was heated at $94^{\circ} \mathrm{C}$ for 5 min, followed by amplification through 35 cycles. Each cycle included denaturation at $94^{\circ} \mathrm{C}$ for $30 \mathrm{~s}$, annealing at $58^{\circ} \mathrm{C}$ for $45 \mathrm{~s}$ and extension at $72^{\circ} \mathrm{C}$ for $90 \mathrm{~s}$. Then $10 \mu \mathrm{L}$ of the PCR product was electrophoresed on a $10 \mathrm{~g} / \mathrm{L}$ agarose gel containing ethidium bromide $(0.5 \mathrm{~g} / \mathrm{mL})$, and visualized under ultraviolet light.

\subsection{Cloning into Vector and Sequencing}

The PCR product was recycled with Plamids Gel Recycle Kit (purchased from BioLabs company), T4 DNA Polymerase (purchased from Takara company) blunt, pUC19 vector was digested using restriction enzyme HincII (purchased from Takara company). The recycled plasmid was inserted in the digested pUC19 vector with T4 DNA Ligase (purchased from Takara company). The ligated plasmids were transformed into engineering bacteria TOP10, the transformed TOP10 was tiled in flat plate contained agar and X-gal. Selecting white colony to sequence.

\subsection{Cloning to pTAT and Prokaryotic Expression}

Designing a set of primers (PF: GCGGGTACCGCGACTCGGCTTGAGGAGGTAACGCGA inlet Kpn I site, PR: CCGCTCGAGGCCTTAAGCAGGAGAACC, inlet XhoI site) and amplifying the sequence enconding using LPS-stimulated NIH3T3 cDNA first-strand construct as template and two franking primers(PF, PR), The PCR reaction was performed using standard protocols with 35 cycles of $30 \mathrm{~s}$ at $94^{\circ} \mathrm{C}, 45 \mathrm{~s}$ at $53.5^{\circ} \mathrm{C}$ and $90 \mathrm{~s}$ at $72^{\circ} \mathrm{C}$. Appropriately sized amplification products were verified by agarose gel electrophoresis. The PCR products were inserted in the multiple cloning site of pTAT (Invitrogen) between KpnI and XhoI, transformed into E. coli BL21(DE3) (stored in our labs) respectively. The individual clones were sequenced. The transformant $E$. coli BL21(DE3) clones were grown at $37.8^{\circ} \mathrm{C}$ to an A600 value of 0.6 in $\mathrm{LB} / \mathrm{ampicillin}(100 \mu \mathrm{g} / \mathrm{ml})$, induced with $1 \mathrm{mM}$ isopropyl thio- $\beta$-D-galactoside (IPTG) and incubated for $3 \mathrm{~h}$. The induced cells were disrupted by sonication and centrifuged at $12,000 \mathrm{rpm}$ for $10 \mathrm{~min}$. Supernatant and sediment were prepared to samples for $12 \%$ SDS-PAGE respectively.

\subsection{Bioinformatics Analysis}

The sequences encoding obtained were searched in UCSC database, and analysis chromosome location and exon/intron boundary (http://genome.ucsc.edu/) [26]. All exon/intron boundaries were shown to follow the canonical ag/gt rule of splicing.

\section{Results}

\subsection{Cloning Two Splicing Products of mLRG cDNA}

The length of applied MLRG cDNA by RT-PCR is 1907 bp (Figure 1), the complete mLRG sequence encoding was known through sequencing, the length of mLRG encoding is 1554 bp (named $\mathrm{mlrgW}$ ), and we got another splicing form sequence encoding about 1407 bp (named mlrgS), mlrgS lock a fragment about 147 bp between $176^{\text {th }}$ and $322^{\text {th }}$ in $m \operatorname{lrg} W$ sequence (Figure 2).

\subsection{Analysis in Murine Genome}

We found a g to a change at $229^{\text {th }}$ nucleotide in the first intron (an amino acid G to D change), a t to g change at $1495^{\text {th }}$ nucleotide in the tenth intron (an amino acid $L$ to $G$ change), a c to $t$ change at $1566^{\text {th }}$ nucleotide in the tenth intron, the stop condon antelocate 18 nucleotides through camparing $\mathrm{mlrg} W$ and $\mathrm{m} \operatorname{lrgS}$ to murine genome in UCSC database. $\mathrm{mlrg} W$ and $\mathrm{mlrgS}$ locate chromosome X qF4 site, $\mathrm{mlrg} W$ and $\mathrm{mlrgS}$ sequence are $99.8 \%$ with homology to murine genome after comparing with sequence in GenBank. Since the genomic organization of $\mathrm{mlrg} W$ and $\mathrm{mlrgS}$ has not been investigated, we also examined the exon/intron structure of the gene by combining genomic and RT-PCR. The sequence encoding of $m \operatorname{lrg} W$ contains 10 exons and 9 introns (Figure 3), and the 


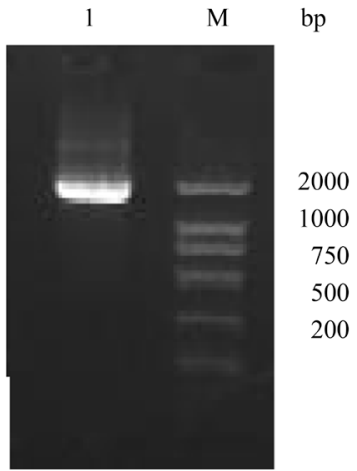

Figure 1. Agrose gel electrophoresis of the PCR product of mLRG cDNA. M: 2000 bp ladder marker; 1 : the PCR product of mLRG cDNA.

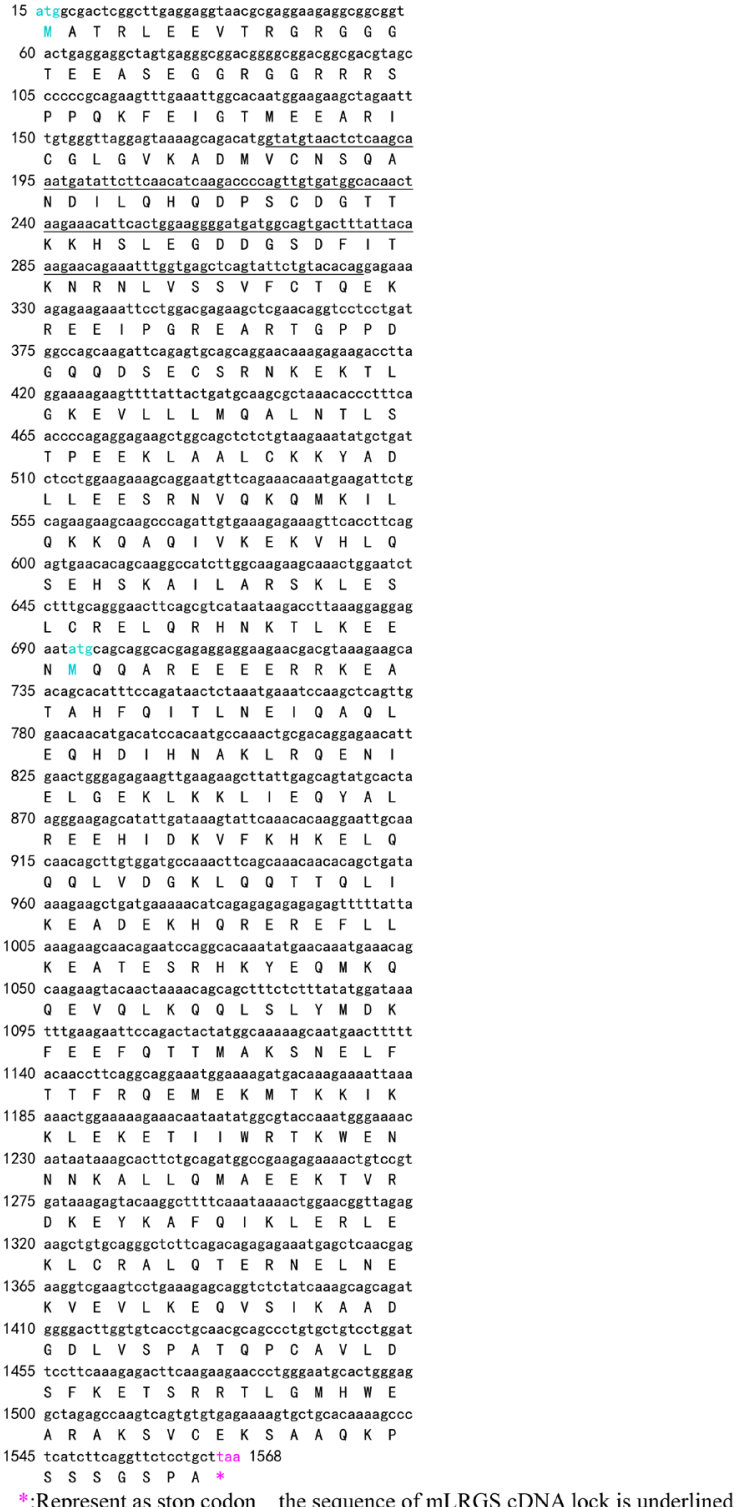

Figure 2. ORF sequence and the deduced amino acid sequence of mLRGW and mLRGS CDNA. 
sequence of $m \operatorname{lrgS}$ contains 11 exons and 10 introns (Figure 4). mlrgS cut out a intron in the second exon of mlrgW, so mlrgS contains 11 exons and 10 introns, it is internal splicing. The open reading frame (ORF) of these two are correct. It demonstrates that these two splicing products of $\mathrm{mlrg}$ are correct different expressions of murine $\operatorname{lrg}$ (Figure 5). They maybe acted as two different roles in responsing to LPS-stimulate.

\subsection{Prokaryotic Protein Expression}

$m \operatorname{lrg} W$ and $m \operatorname{lrgS}$ were cloned to pTAT vector successfully, and results of sequencing were identified with sequence results of $m l r g$-cDNA, pTAT-MLRGW and pTAT-MLRGS were identified using cut with double enzymes (KpnI and $\mathrm{Xhol}$ ), monoenzyme (HindIII) respectively (Figure 6). Figure 7 shows that mlrgS was divided into two fragments (one is about 680 bp, another is about 730 bp) by HindIII. It is not obvious in Agarose gel electrophoresis because two fragments is too close. All identified restriction sites are correct. It demonstrated that mLRGW-pTAT/ BL21(DE3) and mLRGS-pTAT/BL21(DE3) we cloned were right, and can be used to express mLRGW and mLRGS proteins correctly. His-TAT-mLRGW protein contained 468 amino acids band at Mr 66500, and HisTAT-mLRGS protein contained 518 amino acids band at Mr 61,000. The result is concordant with predicted molecular weight. His-TAT-mLRGW and His-TAT-mLRGS were existed in inclusion body. His-TAT-mLRGW and His-TAT-mLRGS were not expressed in mLRGW/BL21(DE3) and mLRGS/BL21-(DE3) without induction. The result demonstrates that mLRGW/BL21(DE3) and mLRGS/BL21(DE3) were inducible (Figure 8).

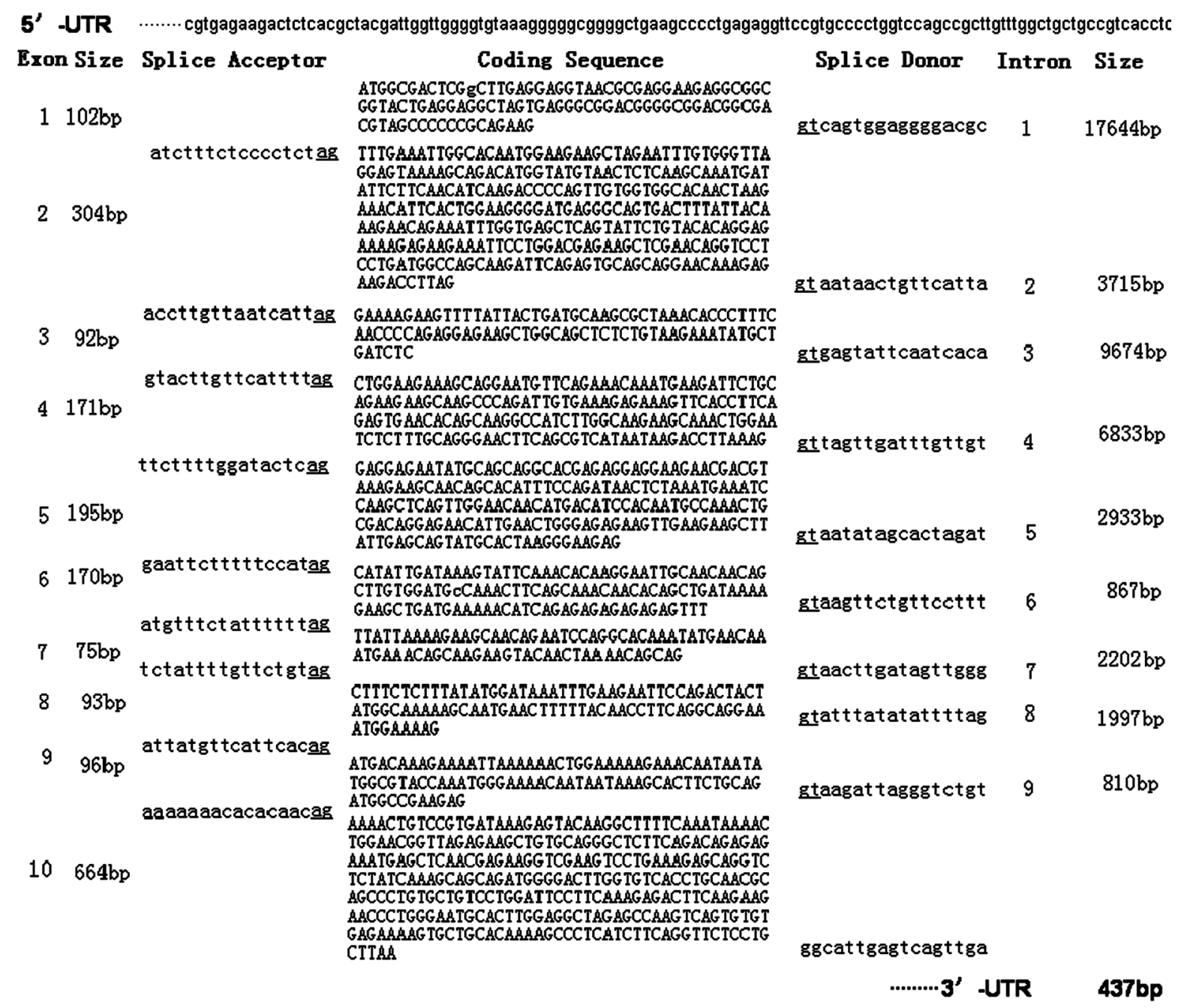

Figure 3. Exon/intron structure of $\mathrm{mlrg} W$. Exon bases are given in capital letters, intron bases in small letters. Canonical $\mathrm{ag} / \mathrm{gt}$ bases at the exon/intron boundaries are underlined. 


\begin{tabular}{|c|c|c|c|c|c|c|}
\hline xor & n Size & Splice Acceptor & Coding Sequence & Splice Donor & Intron & Size \\
\hline 1 & $102 \mathrm{bs}$ & & $\begin{array}{l}\text { ATGGCGACTCGgCTTGAGGAGGTAACGCGAGGABGAGGCGGC } \\
\text { GGTACTGAGGAGGCTAGTGAGGGCGGACGGGGCGGACGGCGA } \\
\text { CGTAGCCCCCCGCAGAAG }\end{array}$ & gtcagtggaggggacgc & 1 & $17644 \mathrm{bp}$ \\
\hline 2 & $60 \mathrm{bp}$ & atcttctcccetctag & $\begin{array}{l}\text { TTTGASATTGGCACAATGGASGAGCTAGAATTTGTGGTTA } \\
\text { GGAGTAAAAGCAGACATG }\end{array}$ & gtatgtaactctcaagc & 2 & $147 \mathrm{bp}$ \\
\hline 3 & $97 \mathrm{bp}$ & accttgttaatcattag & $\begin{array}{l}\text { GAGAARAGAGAAGABATTCCTGGACGAGAAGCTCGAACAGGT } \\
\text { CCTCCTGATGGCCAGCABGATTCAGAG TGCAGCAGGAACAAA } \\
\text { GAGABGACCITAG }\end{array}$ & gtaataactgttcatta & 3 & $3715 \mathrm{bp}$ \\
\hline 4 & $92 \mathrm{bp}$ & cagtattctgtacacag & $\begin{array}{l}\text { GAABAGAAGTTTTATTACTGATGCAAGCGCTAAACACCCTTTC } \\
\text { AACCCCAGAGGAGAGCTGGCAGCTCTCTGTAAGAARTATGCT } \\
\text { GATCTC }\end{array}$ & gtgagtattcaatcaca & 4 & $9674 \mathrm{bp}$ \\
\hline 5 & $171 \mathrm{bp}$ & gtacttgttcattttag & 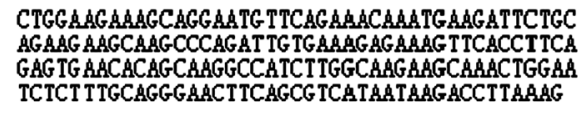 & gttagttgatttgttgt & 5 & $6833 \mathrm{bp}$ \\
\hline 6 & $195 \mathrm{bp}$ & ttctttggatactcag & 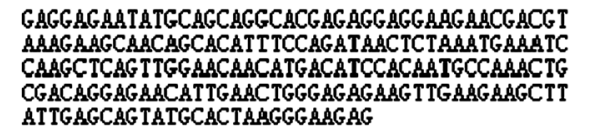 & gtaatatagcactagat & 6 & 2933bp \\
\hline 7 & $170 \mathrm{bp}$ & gaattcttttccatag & $\begin{array}{l}\text { CATAT TGATAABGTATTCAAACACAAGGAATTGCAACAACAG } \\
\text { CTTGTGGATGCCAARCTCAGCAARCAACACAGCTGATAARA } \\
\text { GABGC TGATGARAACCACAGAGAGAGAGAGAGTTT }\end{array}$ & gtaagttctgttcettt & 7 & $867 \mathrm{bp}$ \\
\hline 8 & $75 \mathrm{bp}$ & atgttctatttttag & $\begin{array}{l}\text { TTATTAAABGAAGCAACAGAATCCAGGCACAAATATGAACAA } \\
\text { ATGAAACAGCAAGABGTACABCTAAAACAGCAG }\end{array}$ & gtaact tgatagt tggg & 8 & $2202 \mathrm{bp}$ \\
\hline 9 & $93 \mathrm{bp}$ & tctattttgttctgtag & 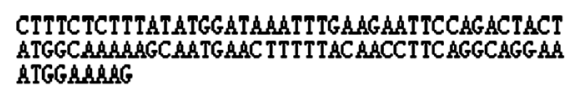 & gtatttatatatttag & 9 & $1997 \mathrm{bp}$ \\
\hline 10 & $96 \mathrm{bp}$ & attatgttcattcacag & 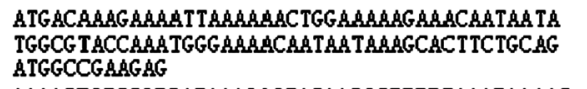 & gtaagat tagggtctgt & 10 & $810 \mathrm{bp}$ \\
\hline \multirow[t]{2}{*}{11} & $664 \mathrm{bp}$ & aaaaaacacacaacag & 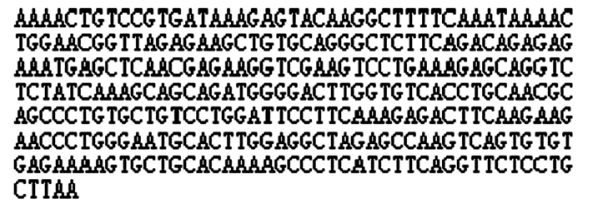 & $\mathrm{gg}$ & & \\
\hline & & & & & & op \\
\hline
\end{tabular}

Figure 4. Exon/intron structure of $m l r g S$. Exon bases are given in capital letters, intron bases in small letters. Canonical ag/gt bases at the exon/intron boundaries are underlined.

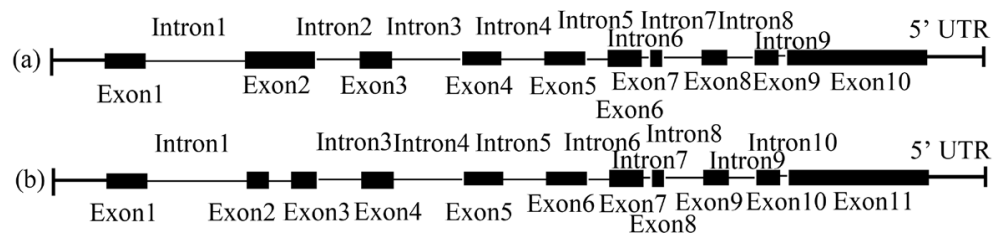

Figure 5. Genomic structure of mLRGW and mLRGS. Introns are represented by a thin line. Exons are depicted by a filled box. (a) Represents mLRGW; (b) Represents mRLGS.

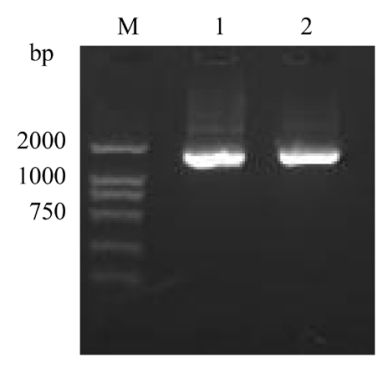

Figure 6. Agarose gel electrophoresis of the PCR product of mLRGW and mLRGS cDNA ORF. M: DNA ladder marker; 1 : the PCR product of encoding the mLRGS protein; 2: the PCR product of encoding the mLRGW protein. 


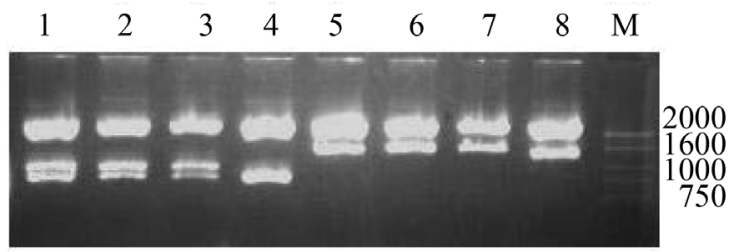

Figure 7. Enzyme digestion analysis of pTAT-MLRGW and pTATMLRGS. M: DNA ladder marker; 1-3: pTAT-MLRGW cut with HindIII; 4: pTAT-MLRGS cut with HindIII; 5-7: pTAT-MLRGW cut with KpnI and XhoI; 8: pTAT-MLRGS cut with KpnI and XhoI.

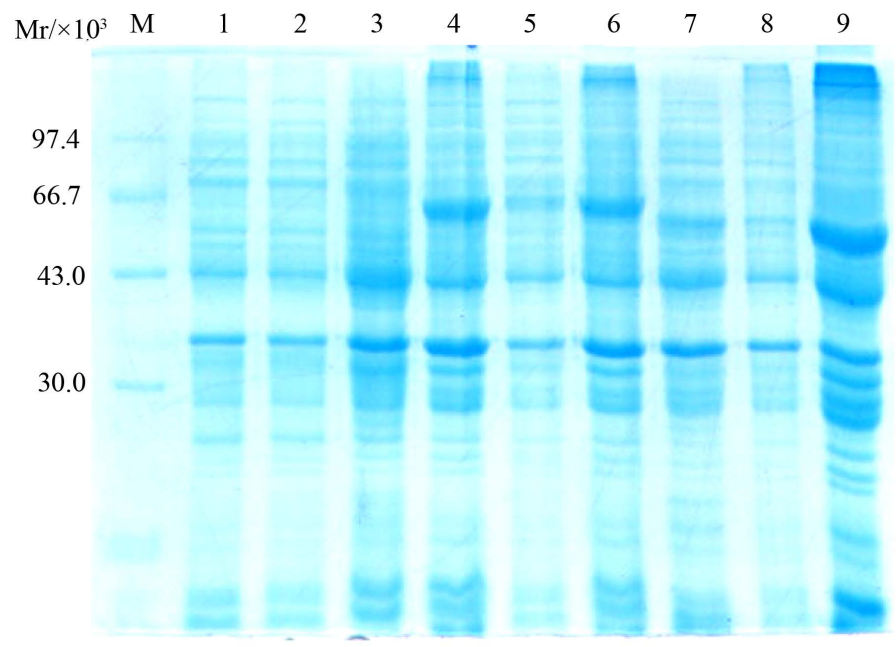

Figure 8. SDS-PAGE analysis of the expression of 6His-TATmLRGW and 6His-TAT-mLRGS fusion protein. M: Protein marker; 1: BL21 transformed by pTAT without induction; 2: BL21 transformed by pTAT induced with IPTG; 3: BL21 transformed by pTATmLRGW without induction;4: BL21 transformed by pTAT-mLRGW induced with IPTG; 5: Supernatant of BL21 transformed by pTATmLRGW induced with IPTG; 6: Precipitation of BL21 transformed by pTAT-mLRGW induced with IPTG; 7: BL21 transformed by pTAT-mLRGS induced with IPTG; 8: Supernatant of BL21 transformed by pTAT-mLRGS induced with IPTG; 9: Precipitation of $B L 21$ transformed by pTAT-mLRGS induced with IPTG.

\section{Conclusions}

To date, we haven't found the investigation of murine gene of lipopolysaccharide response ( $\mathrm{mlrg}$ ).

We predicted the sequence of mLRG cDNA which length is 1905 bp through splicing combined the method of BLASTZ [24] and GenBank database. We demonstrated the sequence of mLRG cDNA through RT-PCR from LPS-stimulated NIH3T3 cells. We synthesized mouse cDNA first-strand from LPS-stimulated NIH3T3 as template again for amplifying mLRG encoding, and we got two splicing products of mLRG encoding (named $m l r g W$ and $m l r g S$ ). Open Reading Frames (ORF) of $m l r g W$ and $m l r g S$ are right. mLRGW contains 518 amino acids, and mLRGS contains 468 amino acids. Calculated molecular mass of mLRGW is 66,500 Da, and that of mLRGS is 61,000 Da.

$\mathrm{mlrg} W$ and $\mathrm{mlrgS}$ are located at chromosome X qF4 site, and the sequence of them are $99.8 \%$ homology with murine genome through comparing the sequence of them to the sequence of murine genome in GenBank database. We found that mlrgW contained 10 exons and 9 introns, and mlrgS contained 11 exons and 10 introns through synthesized exon/intron boundary of $\mathrm{mlrg} W$ and $\mathrm{m} \operatorname{lrgS}$ in UCSC database. The second and third exons of $m \operatorname{lrgS}$ are contained in the second exons of $m \mathrm{lrg} W$, and $\mathrm{mlrgS}$ locks a fragment as an intron in the second exon of $m \operatorname{lrgW}$. This form of splicing is internal splicing. Cloning and expressing $m \operatorname{lrg} W$ and $m \operatorname{lrgS}$ successfully is 
help of study function of human lrg.

Further bioinformatics analysis shows $m \operatorname{lrg} W$ and $m \operatorname{lrgS}$ contain a Leucine Zipper domain between $431^{\text {th }}$ and $468^{\text {th }}$ amino acids motif at mlrgW and a domain between $606^{\text {th }}$ and $807^{\text {th }}$ nucleotide motif at $\mathrm{mlrgW}$ matches Pfam-B 27780 associated with Zinc Finger Protein (ZIP) $\mathrm{C}_{2} \mathrm{H}_{2}$ type in the Protein families database (Pfam database). The GAG (=CTC) repeat among Zinc Finger Protein (ZIP) $\mathrm{C}_{2} \mathrm{H}_{2}$ type constitutes a high-affinity site for Sp1 binding to the wt1 remoter. These manifest that $\mathrm{mlrg}$ maybe involved in transcription regulation. Leucine zipper domain is the property domain of DNA binding protein [27], but it is riddle which proteins $\mathrm{mlrg}$ bind with.

Former studies show over-expression human $\operatorname{lrg}$ can inhibit at $\mathrm{G}_{0}$ stage of cell cycle in $\operatorname{lrg}$-transfected human embryo kidney cells and HepG2 cells. mlrg maybe involved in the procedure of oxidative stress, and then impact cell cycle. We are going to demonstrate the mechanism of lrg impact cell cycle through further experiment.

\section{References}

[1] Wright, S.D., Ramos, R.A., Tobias, P.S., Ulevitch, R.J. and Mathison, J.C. (1990) CD14, a Receptor for Complexes of Lipopolysaccharide (LPS) and LPS Binding Protein. Science, 249, 1431-1433. http://dx.doi.org/10.1126/science.1698311

[2] Poltorak, A., He, X., Smirnova, I., Liu, M.Y., Van Huffel, C., Du, X., Birdwell, D., et al. (1998) Defective LPS Signaling in C3H/HeJ and C57BL/10ScCr Mice: Mutations in Tlr4 Gene. Science, 282, 2085-2088. http://dx.doi.org/10.1126/science.282.5396.2085

[3] Hoshino, K., Takeuchi, O., Kawai, T., Sanjo, H., Ogawa, T., Takeda, Y., et al. (1999) Cutting Edge: Toll-Like Receptor 4 (TLR4)-Deficient Mice Are Hyporesponsive to Lipopolysaccharide: Evidence for TLR4 as the Lps Gene Product. Journal of Immunology, 162, 3749-3752.

[4] Frey, E.A., Miller, D.S., Jahr, T.G., Sundan, A., Bazil, V., Espevik, T., et al. (1992) Soluble CD14 Participates in the Response of Cells to Lipopolysaccharide. Journal of Experimental Medicine, 176, 1665-1671. http://dx.doi.org/10.1084/jem.176.6.1665

[5] Haziot, A., Rong, G.W., Silver, J. and Goyert, S.M. (1993) Recombinant Soluble CD14 Mediates the Activation of Endothelial Cells by Lipopolysaccharide. Journal of Immunology, 151, 1500-1507.

[6] Pugin, J., Schurer-Maly, C.C., Leturcq, D., Moriarty, A., Ulevitch, R.J. and Tobias, P.S. (1993) Lipopolysaccharide Activation of Human Endothelial and Epithelial Cells Is Mediated by Lipopolysaccharide-Binding Protein and Soluble CD14. Proceedings of the National Academy of Sciences of the USA, 90, 2744-2748. http://dx.doi.org/10.1073/pnas.90.7.2744

[7] Zhang, F.X., Kirschning, C.J., Mancinelli, R., Xu, X.P., Jin, Y., Faure, E., et al. (1999) Bacterial Lipopolysaccharide Activates Nuclear Factor-KappaB through Interleukin-1 Signaling Mediators in Cultured Human Dermal Endothelial Cells and Mononuclear Phagocytes. Journal of Biological Chemistry, 274, 7611-7614. http://dx.doi.org/10.1074/jbc.274.12.7611

[8] Hijiya, N., Miyake, K., Akashi, S., Matsuura, K., Higuchi, Y. and Yamamoto, S. (2002) Possible Involvement of TollLike Receptor 4 in Endothelial Cell Activation of Larger Vessels in Response to Lipopolysaccharide. Pathobiology, 70, 18-25. http://dx.doi.org/10.1159/000066000

[9] Ferrero, E., Jiao, D., Tsuberi, B.Z., Tesio, L., Rong, G.W., Haziot, A., et al. (1993) Transgenic Mice Expressing Human CD14 Are Hypersensitive to Lipopolysaccharide. Proceedings of the National Academy of Sciences of the USA, 90, 2380-2384. http://dx.doi.org/10.1073/pnas.90.6.2380

[10] Tamura, Y., Higuchi, Y., Kataoka, M., Akizuki, S., Matsuura, K. and Yamamoto, S. (1999) CD14 Transgenic Mice Expressing Membrane and Soluble Forms: Comparisons of Levels of Cytokines and Lethalities in Response to Lipopolysaccharide between Transgenic and Non-Transgenic Mice. International Immunology, 11, 333-339. http://dx.doi.org/10.1093/intimm/11.3.333

[11] Haziot, A., Ferrero, E., Kontgen, F., Hijiya, N., Yamamoto, S., Silver, J., et al. (1996) Resistance to Endotoxin Shock and Reduced Dissemination of Gram-Negative Bacteria in CD14-Deficient Mice. Immunity, 4, 407-417. http://dx.doi.org/10.1016/S1074-7613(00)80254-X

[12] Kitchens, R.L. and Thompson, P.A. (2005) Modulatory Effects of sCD14 and LBP on LPS-Host Cell Interactions. Innate Immunity, 11, 225-229. http://dx.doi.org/10.1177/09680519050110040701

[13] Lakics, V. and Vogel, S. (1998) Lipopolysaccharide and Ceramide Use Divergent Signaling Pathways to Induce Cell Death in Murine Macrophages. The Journal of Immunology, 161, 2490-2500.

[14] Xaus, J., Comalada, M., Valledor, A., Lioberas, J., Soriano, L., Argiles, J., Bogdan, C. and Celada, A. (2000) LPS Induces Apoptosis in Macrophages Mostly through the Autocrine Production of TNF-Alpha. Blood, 95, 3823-3831. 
[15] Soler, C., Valdes, R., Garcia-Manteiga, J., Xaus, J., Comalada, M., Casado, F., Modolell, M., Nicholson, B., MacLeod, C., Felipe, A., Celada, A. and Pastor-Anglada, M. (2001) Lipopolysaccharide-Induced Apoptosis of Macrophages Determines the Up-Regulation of Concentrative Nucleoside Transporters Cnt1 and Cnt2 through Tumor Necrosis Factor- $\alpha$-Dependent and -Independent Mechanisms. The Journal of Biological Chemistry, 276, 30043-30049. http://dx.doi.org/10.1074/jbc.M101807200

[16] Hachiya, O., Takeda, Y., Miyata, H., Watanabe, H., Yamashita, T. and Sendo, F. (1995) Inhibition by Bacterial Lipopolysaccharide of Spontaneous and TNF- $\alpha$-Induced Human Neutrophil Apoptosis in Vitro. Microbiology and Immunology, 39, 715-723. http://dx.doi.org/10.1111/j.1348-0421.1995.tb03247.x

[17] Akgul, C., Moulding, D. and Edwards, S. (2001) Molecular Control of Neutrophil Apoptosis. FEBS Letters, 487, 318322. http://dx.doi.org/10.1016/S0014-5793(00)02324-3

[18] Wang, S., Huang, K., Lin, Y. and Lei, H. (1994) Sepsis-Induced Apoptosis of the Thymocytes in Mice. The Journal of Immunology, 152, 5014-5021.

[19] Manhart, N., Vierlinger, K., Habel, O., Bergmeister, L., Gotzinger, P., Sautner, T., Spittler, A., Boltznitulescu, G., Marian, B. and Roth, E. (2000) Lipopolysaccharide Causes Atrophy of Peyer's Patches and an Increased Expression of CD28 and B7 Costimulatory Ligands. Shock, 14, 478-483. http://dx.doi.org/10.1097/00024382-200014040-00010

[20] Feterowski, C., Weighardt, H., Emmanuilidis, K., Harung, T. and Hozmann, B. (2001) Immune Protection against Septic Peritonitis in Endotoxin-Primed Mice Is Related to Reduced Neutrophil Apoptosis. European Journal of Immunology, 31, 1268-1277. http://dx.doi.org/10.1002/1521-4141(200104)31:4<1268::AID-IMMU1268>3.0.CO;2-C

[21] Alikhani, M., Alikhani, Z., He, H., Liu, R., Popek, B.I. and Graves, D.T. (2003) Lipopolysaccharides Indirectly Stimulate Apoptosis and Global Induction of Apoptotic Genes in Fibroblasts. The Journal of Biological Chemistry, 278, 52901-52908. http://dx.doi.org/10.1074/jbc.M307638200

[22] Chai, Y.B. and Zhao, Z.L. (2000) Improved PCR-Based Subtractive Hybridization Strategy for Cloning Differentially Expressed Genes. Biotechniques, 29, 310-313.

[23] Zhao, Z.L. and Chai, Y.B. (1999) Direct Cloning of Cell Differential Expression Genes with Full Length by a New Strategy. Journal of Biotechnology, 73, 35-42. http://dx.doi.org/10.1016/S0168-1656(99)00006-1

[24] Schwartz, S., Kent, W.J., Smit, A., Zhang, Z., Baertsch, R., Hardison, R.C., Haussler, D. and Miller, W. (2004) Human-Mouse Alignments with BLASTZ. Genome Research, 14, 786.

[25] Kawai, J., Shinagawa, A., Shibata, K., Yoshino, M., Itoh, M., Ishii, Y., et al. (2001) Functional Annotation of a FullLength Mouse cDNA Collection. Nature, 409, 685-690. http://dx.doi.org/10.1038/35055500

[26] Schafflera, A., Ehlinga, A., Neumanna, E., Herfarth, H., Tarner, I., Gay, S., Schölmerich, J. and Müller-Ladner, U. (2003) Genomic Organization, Chromosomal Localization and Adipocytic Expression of the Murine Gene for CORS26 (Collagenous Repeat-Containing Sequence of 26 kDa Protein). Biochimica et Biophysica Acta, 1628, 64-70. http://dx.doi.org/10.1016/S0167-4781(03)00114-3

[27] Medici, N., Abbondanza, C. and Nigro, V. (1999) Identification of a DNA Binding Protein Cooperating with Estrogen Receptor as RIZ (Retinoblastoma Interacting Zinc Finger Protein). Biochemical and Biophysical Research Communications, 264, 983-989. http://dx.doi.org/10.1006/bbrc.1999.1604 